Саамский язык: проблемы сохранения и функционирования миноритарного языка в условиях русскоязычного окружения

Иванищева О.Н.

ФГБОУ ВО «Мурманский арктический государственный университет»,

Мурманск, Российская Федерация.

(i) https://orcid.org/0000-0001-8495-0502, e-mail: oivanishcheva@gmail.com

Резюме: В статье представлен анализ социолингвистической ситуации на Кольском Севере с кильдинским саамским языком. Цель статьи: рассмотреть исторические причины положения коренного малочисленного языка Севера, а также современное положение с образовательными программами по кильдинскому саамскому языку. Методы. Использован описательный метод. Результат анализа состоит в том, что указаны направления деятельности государственных структур и саамских активистов по улучшению функционирования языка, показано, что в условиях русскоязычного окружения шанс на выживание миноритарного языка имеет дистанционное образование, даны рекомендации к мероприятиям по сохранению и ревитализации кильдинского саамского языка. Делается вывод о том, что наиболее подходящей технологией обучения дисперсно проживающего населения является организация обучения на основе специально подготовленных дистанционных курсов, объединенных в единую систему на учебном портале, на котором организовано не только обучение в форме передачи учебного и методического материала обучаемому для усвоения, но и проводится контроль и оценка полученных знаний в асинхронном режиме, анализ качества прохождения учебного материала.

Ключевые слова: дистанционное образование, саамский язык, русскоязычное окружение.

Для цитирования: Иванищева О.Н. Саамский язык: проблемы сохранения и функционирования миноритарного языка в условиях русскоязычного окружения // Этническая культура. - 2019. - № 1 (1). - С. $24-26$. DOI:10.31483/r-64074.

\title{
Kola Saami Languages: Problem of Language Preservatiom and Functioning in the Urban Environment
}

\author{
Olga N. Ivanishcheva \\ FSBEI HE "Murmansk Arctic State University", \\ Murmansk, Russian Federation. \\ https://orcid.org/0000-0001-8495-0502, e-mail: oivanishcheva@gmail.com
}

\begin{abstract}
The article presents an analysis of the sociolinguistic situation in the Kola North with the Kildin Saami language. Purpose of work - to consider the historical reasons for the situation of the indigenous language of the North, as well as the current situation with educational programs in the Kildin Saami language. The following method was used in the study: descriptive method. The result of the analysis is that in the study indicates the directions of activity of state structures and Saami activists to improve the functioning of the language, shows that in the conditions of the Russianspeaking environment, the chance for the survival of a minority language has a distance education, recommendations to the activities for conservation and revitalization Kildin Saami language. The study showed that the most suitable teaching technology for the dispersed population is the organization of training on the basis of specially prepared distance learning courses integrated into a single system on the training portal, which not only organizes training in the form of transferring teaching and methodological material to the learner for assimilation, but also monitors and evaluates the knowledge gained in asynchronous mode, analysis of the quality of the passage of educational material.
\end{abstract}

Keywords: distance education, Saami language, Russian-speaking environment.

For citation: Ivanishcheva O.N. (2019). Kola Saami Languages: Problem of Language Preservatiom and Functioning in the Urban Environment. Etnicheskaya kultura = Ethnic Culture, 1(1), 24-26. (In Russ.) DOI:10.31483/r-64074.

\section{Введение}

пецифика ситуации такого коренного малочисленного народа Севера, как саамы, состоит в том, что саамский народ исторически разделен и проживает в 4 странах: России, Финляндии, Норвегии и Швеции. Саамы России (кольские саамы) в основном проживают на территории Кольского полуострова, где находится административное образование Мурманская область. Цель статьи - рассмотреть исторические причины положения коренного малочисленного языка Севеpa, а также современное положение с образовательными программами по кильдинскому саамскому языку.

На основе описательного метода были получены результаты, представляющие следующую информацию.

Примерно с XVII в., как утверждают ученые-историки, саамы разных языковых наречий на территории
Русского Севера общались между собой на русском языке, так как плохо понимали речь друг друга. Постепенно социально-экономические условия и политика Российского государства до и после революции 1917 года привели к тому, что саамы практически утратили свой язык и 100\% овладели русским языком.

Саамов, по замечанию известного исследователя саамского языка и культуры Г.М. Керта, отторгли от привычной среды обитания: отрасли хозяйства, считавшиеся исконно саамскими, подчинены государственным структурам и не приносят того дохода саамскому населению, который могли бы [9, с. 42]. Саамы составляют 0,15\% населения Мурманской области. В последние годы отмечается некоторая динамика численности саамского населения. Это, однако, не означает изменения демографической ситуации: смертность среди корен- 
ного населения высокая, а рождаемость, как и по всей России, низкая. Увеличение численности связано с фактором национального самосознания: все больше и больше представителей народности осознают себя частью своего народа и заявляют свою национальность.

Большая часть саамов проживает в различных городах Мурманской области (городское население): Мурманск - 139 человек, Апатиты - 53 человека, ЗАТО Островной - 33, Оленегорск - 46, Мончегорск - 43, ЗАТО Североморск - 22, Кола - 83, Кандалакша - 13, Кировск - 12, Полярные Зори - 10, ЗАТО Александровск - 20 [8]. Дисперсность проживания саамов препятствует их общению на родном языке: районы компактного проживания саамов в Мурманской области расположены в разных частях полуострова в удалении от областного центра г. Мурманска. Недостаточно развитая транспортная инфраструктура и высокая стоимость транспортных услуг и проживания является одним из существенных препятствий для обучения представителей коренного населения в областном центре - г. Мурманске или в другом городе.

Обсуждение. В настоящее время естественной передачи саамского языка новым поколениям не существует, поскольку в семьях практически не говорят на этом языке. Преподавание кильдинского саамского языка в настоящее время не существует: в средней школе с. Ловозеро саамский язык не преподают, даже на уровне факультативного курса, хотя краткосрочные курсы кильдинского саамского языка проводятся по инициативе саамского сообщества. В последнее время активизировались интерактивные формы изучения языка. Так, в январе 2019 года возникла идея проекта «Са̄ppн са̄мас». В. Совкина представила в рамках «Кольского саамского радио» флешмоб «Говори, как умеешь», или «Са̄ррн са̄мас» (говори по-саамски). Престиж родного языка среди саамов, к сожалению, довольно низок, на это имеется ряд причин: экономических, социальных и политических. Изучать свой язык в основном хотят представители старшего поколения (старше 70 лет).

В условиях русскоязычного окружения проблема сохранения и функционирования языка коренного малочисленного народа (саамского языка) в Мурманской области имеет несколько аспектов.

С одной стороны, доминирование русскоязычной среды привело к тому, что русский язык вытеснил саамский язык из всех сфер использования языка (официальных и неофициальных). В сельских районах Мурманской области саамский язык отмечен в бытовом общении. Использование саамского языка в общественной жизни очень ограниченно. Исключение составляет, пожалуй, только реализация проекта саамское радио, которая началась в 2003 г., а практически закончилась в 2010 г., когда прокурор Ловозерского района возбудил производство дела об административном правонарушении в отношении юридического лица - ЗАО «Кольское саамское радио» по ч. 1 ст. 5.27 Законодательства о труде.

С другой стороны, возможность изучения саамского языка в городской среде более реальна за счет наличия технических и человеческих ресурсов.
Наши исследования показали, что в центре компактного проживания кольских саамов в с. Ловозеро Мурманской области в школе-интернате в начальной школе до 2017 года было выделено всего 2 часа факультатива на саамский язык (2 раза в неделю), на коми - 1 час. В профессиональном училище №26, расположенном в с. Ловозеро, ведется обучение саамскому языку и традиционным саамским промыслам по специальностям оленевод, резчик по кости и дереву, мастер пошива изделий из меха, хозяйка усадьбы. Успешно реализуются совместные проекты с профессиональными учебными заведениями Финляндии и Норвегии, в том числе проект дистанционного обучения оленеводству. И даже там на 1 курсе есть всего 36 часов саамского языка по учебной программе в год, на 2 курсе - 35 часов, на 3 курсе - 30 часов. Постоянного расписания для этих уроков нет. В быту знания не используют, теорию языка не учат, занимаются разговорным языком. В детском саду №2 с. Ловозеро была саамская группа приблизительно из 10 человек разновозрастных детей, которые занимаются только разговорной речью. До последнего времени было несколько языковых курсов, в том числе в г. Мурманске (преподаватель - Р.И. Яковлева), в п. Ёна (преподаватель - Т.Ф. Цмыкайло), в с. Ловозеро в Национальном культурном центре (преподаватель А. Яковлева), в офисе Центра саамских знаний (преподаватель - М.Г. Медведева). Проблема преподавания саамского, по мнению А.А. Антоновой, создателя саамского словаря, поэтессы и общественного деятеля, состоит в том, что преподаватели ориентируются на разговорный язык, не изучают грамматики. В г. Мурманске в 2003 году в гимназии №9 было преподавание саамского языка в начальной школе (преподаватель Н.А. Золотухина), но только в течение полугода. Что касается изучения культуры и истории саамского народа в средних образовательных учреждениях, то в 9 классе общеобразовательной школы 1 час из 3 часов, предназначенных для преподавания истории, официально отводится на изучение курса «История Кольского Севера с древнейших времен до начала XXI века». Но не все преподаватели истории используют этот час по прямому назначению. Историю и культуру саами можно преподавать только как факультатив, кружок или как внеклассное чтение, например на уроках литературы. Раньше была программа регионального компонента в школах города и области, но сейчас очень многое оставляется на усмотрение учителя.

В период с 1926 по 1937 гг. активно публиковалась учебная литература на саамском языке, на всей территории области осуществлялось обучение саамского населения на родном языке и подготовка необходимых кадров.

Разработка и издание учебно-методической литературы для обучения саамскому языку были возобновлены лишь в 1980-е гг. в связи с публикацией букваря А.А. Антоновой $[1 ; 2]$.

В 1990-х гг. учебно-методическая работа по саамскому языку активно осуществлялась группой авторов под руководством Р.Д. Куруч: были разработаны и опубликованы программы, методические руководства, учебные пособия и дидактические материалы для обучения саамскому языку в начальной школе [5]. 
Заключение. Таким образом, существующее на сегодняшний день учебно-методическое обеспечение остается ограниченным ступенью начальной школы, а учебная литература представлена букварями и книгами для чтения, подготовленными в 30-е гг. XX века 3. Черняковым и А. Эндюковским на основе латинской графики [7; 10], и подготовленными в конце XX века букварями А.А. Антоновой [3], школьным саамско-русским и русско-саамским словарем Г.М. Керта [4] и саамско-русским и русско-саамским словарем под редакцией Р.Д. Куруч [6], также многочисленными пособиями начала XXI века.

В такой ситуации, когда саамский язык находится под большой угрозой исчезновения, необходимо:

- рекомендовать соответствующим структурам принять гибкие и новаторские меры в целях сохранения этого языка. Например, в дошкольные учреждения можно регулярно приглашать носителей языка преклонного возраста, чтобы они могли играть с детьми, используя саамский язык;

- начать работу по разработке магистерской программы при университете, которая позволит более подробно изучать язык и культуру кольских саами.

Одним из способов возрождения языка может быть дистанционное обучение.

Важную роль в обосновании значимости организации дистанционного обучения коренного населения области играет геополитический фактор: районы их компактного проживания расположены в разных частях полуострова в удалении от областного центра. А недостаточно развитая транспортная инфраструктура и высокая стоимость транспортных услуг и проживания является одним из существенных препятствий для обучения представителей коренного населения в областном центре.

Таким образом, наиболее подходящей технологией обучения дисперсно проживающего населения является организация обучения на основе специально подготовленных дистанционных курсов, объединенных в единую систему на учебном портале, на котором организовано не только обучение в форме передачи учебного и методического материала обучаемому для усвоения, но и проводится контроль и оценка полученных знаний в асинхронном режиме, анализ качества прохождения учебного материала.

Такая система должна строиться с учётом комплексного подхода, предусматривающего помимо обучения языку возможность создания искусственной языковой среды (веб-чат, голосовой чат, форум), которая позволит обеспечить возможность группового и личного общения между носителями саамского языка, проживающими в разных районах.

\section{Список литературы}

1. Антонова А.А. Букварь для подготовительного класса саамских школ. - Л.: Просвещение, 1982. - 128 с.

2. Антонова А.А. Букварь: учеб. для 1 кл. саам. шк. - СПб.: Дрофа, 2004. - 119 с.

3. Антонова А.А. Саамско-русский словарь. - Мурманск: Лема, 2014. - 376 с.

4. Керт Г.М. Словарь саамско-русский и русско-саамский: пособие для уч-ся нач. шк. - Л.: Просвещение, 1986. - 247 c.

5. Куруч Р.Д. Программа по саамскому языку для I-II классов саамской национальной школы. - М.; Мурманск: Изд-во ИЯ АН СССР, 1990. - 48 с.

6. Саамско-русский словарь / Н.Е. Афанасьева [и др.]; под ред. Р.Д. Куруч. - М.: Русский язык, 1985. - 568 с.

7. Эндюковский А.Г. Саамский букварь. - М.; Л.: Учпедгиз: Ленинградское отделение, 1937. - 106 с.

8. Национальный состав и владение языками, гражданство населения Мурманской области. Итоги Всероссийской переписи населения. Т. 4. Кн. 2. - Мурманск, 2013. - С. 450-451.

9. Прибалтийско-финские народы России / отв. ред. Е.И. Клементьев, Н.В. Шлыгина. - М.: Наука, 2003. - 671 с. 10. Saam, Bukvaє / [kirjixine Saxkri Cerniakonin]. - Moskva-Leningrat: Vєpedgiz, 1933. - 70 p.

\section{References}

1. Antonova, A. A. (1982). Bukvar' dlia podgotovitel'nogo klassa saamskikh shkol., 128. L.: Prosveshchenie.

2. Antonova, A. A. (2004). Bukvar'., 119. SPb.: Drofa.

3. Antonova, A. A. (2014). Saamsko-russkii slovar'., 376. Murmansk: Lema.

4. Kert, G. M. (1986). Slovar' saamsko-russkii i russko-saamskii., 247. L.: Prosveshchenie.

5. Kuruch, R. D. (1990). Programma po saamskomu iazyku dlia I-II klassov saamskoi natsional'noi shkoly., 48. M.;; Murmansk: Izd-vo IIa AN SSSR.

6. Kuruch, R. D., \& Afanas'eva, N. E. (1985). Saamsko-russkii slovar'., 568. M.: Russkii iazyk.

7. Endiukovskii, A. G. (1937). Saamskii bukvar'., 106. M.;; L.: Uchpedgiz; L.: Leningradskoe otdelenie.

8. (2013). Natsional'nyi sostav i vladenie iazykami, grazhdanstvo naseleniia Murmanskoi oblasti. Itogi Vserossiiskoi perepisi naseleniia. T. 4. Kn. 2., 450-451. Murmansk.

9. Klement'ev, E. I., \& Shlygina, N. V. (2003). Pribaltiisko-finskie narody Rossii., 671. M.: Nauka.

10. (1933). Saam Bukvaie. Moskva-Leningrat: V[?]pedgiz.

\section{Информация об авторе}

Иванищева Ольга Николаевна - д-р филол. наук, профессор кафедры русского языка и массовых коммуникаций, ФГБОУ ВО «Мурманский арктический государственный университет», Мурманск, Российская Федерация.

\section{Information about the author}

Olga N. Ivanishcheva - doctor of philological sciences, professor at Russian Language and Mass Communication Department, FSEI of HPE "Murmansk Arctic State University", Murmansk, Russian Federation. 